University for Business and Technology in Kosovo

UBT Knowledge Center

Nov 2nd, 2:15 PM - 2:30 PM

\title{
Extradition as a kind of international cooperation between countries, with special reference to the European Convention on Extradition and the Additional Protocols
}

Armend Asllani

State University of Tetovo

Follow this and additional works at: https://knowledgecenter.ubt-uni.net/conference

Part of the Law Commons

\section{Recommended Citation}

Asllani, Armend, "Extradition as a kind of international cooperation between countries, with special reference to the European Convention on Extradition and the Additional Protocols" (2013). UBT International Conference. 47.

https://knowledgecenter.ubt-uni.net/conference/2013/all-events/47

This Event is brought to you for free and open access by the Publication and Journals at UBT Knowledge Center. It has been accepted for inclusion in UBT International Conference by an authorized administrator of UBT Knowledge Center. For more information, please contact knowledge.center@ubt-uni.net. 


\title{
Extradition as a kind of international cooperation between countries, with special reference to the European Convention on Extradition and the Additional Protocols
}

\author{
Armend Asllani \\ State University of Tetovo \\ Department of Criminal Justice, Law faculty-Tetovo
}

\begin{abstract}
Extradition presents a form of co-operation between states. Almost every state with its domestic and international regulations pays specific importance to this kind of cooperation with the only purpose to prevent or fight the prevalent form of criminal offence that involves an international element, which has been present in many countries of the world during the last centuries, respectively in the XIX century.

In this paperwork, we will commit ourselves to key regulations required by the European Convention and the additional protocols on Extradition.

Herein, some explanation of articles for the extradition request regulations for criminal offence will be provided and analyzed. Then, cases of rejection of extradition, extradition of citizens of the resident state, procedures, and other regulations that applies to this paperwork.
\end{abstract}

Key words: convention, protocol, party, extradition, reserve

\section{Introduction}

The mobility of the contemporary individual frequently as sociated with intense social communication, as well as accompanied with numerous and inevitable barriers in the state borders results in increasing number of the criminal activities which are committed by the foreigners and / or are done against them. The Contracting Parties undertake to surrender to each other, subject to the provisions and conditions laid down in this Convention, all persons against whom the competent authorities of the requesting Party are proceeding for an offence or who are wanted by the said authorities for the carrying out of a sentence or detention order. As stated above, this is included in the European Convention for extradition (Paris, 13.12.1957). This convention along with four additional protocols was also ratified by our country, and with this, Republic of Macedonia has gained the right to implement the dispositions of this convention in its territory.

\subsection{European Convention on extradition}

The contracting parties undertake to surrender to each other all persons against whom the competent authorities of the requesting Party are proceeding for an offence or who are wanted by the said authorities for carrying out of a sentence or detention order.

\subsection{Extraditable offences}

Extradition shall be granted in respect of offences punishable under the laws of the requesting Party and of the requested Party by deprivation of liberty or under a detention order for a maximum period of at least one year or by a more severe penalty. Where a conviction and pris on sentence have occurred or a detention order has been made in the territory of the requesting party, the punishment awarded must have been for a period of at least four months.

If the request for extradition includes several separate offences each of which is punishable under the laws of the requesting Party and the requested Party by deprivation of liberty or under a detention order, but of which some do not fulfill the condition with the regard to the amount of punishment which may be awarded, the requested Party shall also have the right to grant extradition for the latter offences.

Any contracting Party whose law does not allow extradition for certain of the offences referred to in paragraph 1 of this article may, in so far as it is concerned, exclude such offences from the application of this Convention. Any Contracting Party which wishes to avail itself of the right provided for in paragraph 3 of this article shall, at the time of deposit of its instrument of ratification or accession, 
transmit to the Secretary General of the Council of Europe either a list of the offences for which extradition is allowed or a list of those for which it is excluded and shall at the same time indicate the legal provisions which allow or exclude extradition. The Secretary General of the Council shall forward these lists to the other signatories. If extradition is subsequently excluded in respect of other offences by the law of a Contracting Party, that Party shall notify the Secretary General. The Secretary General shall inform the other signatories. Any Party which avails itself of the right provided for in paragraph 4 and 5 of this article may at any time apply this Convention to offences which have been excluded from it. It shall inform the other signatories. Any party may apply reciprocity in respect of any offences excluded from the application of the Convention under this article.

\subsection{Political offences}

Extradition shall not be granted if the offence in respect of which it is requested is regarded by the requested Party as a political offence or as an offence connected with a political offence.

The same rule shall apply if the requested Party has substantial grounds for believing that a request for extradition for an ordinary criminal offence has been made for the purpose of prosecuting or punishing a person on account of his race, religion, nationality or political opinion, or that that person's position may be prejudiced for any of these reasons.

The taking or attempted taking of the life of a Head of State or a member of his family shall not be deemed to be a political offence for the purposes of this Convention.

This article shall not affect any obligations which the Contracting Parties may have undertaken or may undertake under any other international convention of a multilateral character. This section shall not affect any obligations that may be taken by the parties or that may be undertaken under other international conventions. Particularly, it is referred to the four Red Cross conventions, signed in Geneva in 1949, and the convention for the suppression of genocide. Extradition for offences under military law which are not offences under ordinary criminal law is excluded from the application of this Convention.

For offences in connection with taxes, duties, customs and exchange extradition shall take place between the Contracting Parties in accordance with the provisions of the Convention if the offence, under the law of the requested Party, corresponds to an offence of the same nature.Extradition may not be refused on the ground that the law of the requested Party does not impose the same kind of tax or duty or does not contain a tax, duty, custom or exchange regulation of the same kind as the law of the requesting Party."

\subsection{Extradition of nationals}

A Contracting Party shall have the right to refuse extradition of its nationals.

Each Contracting Party may, by a declaration made at the time of signature or of deposit of its instrument of ratification or accession, define as far as it is concerned the term "nationals" within the meaning of this Convention.

Nationality shall be determined as at the time of the decision concerning extradition. If, however, the person claimed is first recognized as a national of the requested Party during the period between the time of the decision and the time contemplated for the surrender, the requested Party may avail itself of the provision contained in sub-paragraph a of this article.

If the requested Party does not extradite its national, it shall at the request of the requesting Party submit the case to its competent authorities in order that proceedings may be taken if they are considered appropriate. For this purpose, the files, information and exhibits relating to the offence shall be transmitted without charge by the means provided for in Article 12, Paragraph 1. The requesting Party shall be informed of the result of its request.

\subsection{The request and supporting documents}

The request shall be in writing and shall be communicated through the diplomatic channel. Other means of communication may be arranged by direct agreement between two or more Parties.

The request shall be supported by: a the original or an authenticated copy of the conviction and sentence or detention order immediately enforceable or of the warrant of arrest or other order having the same effect and issued in accordance with the procedure laid down in the law of the requesting Party; 
a statement of the offences for which extradition is requested. The time and place of their commission, their legal descriptions and a reference to the relevant legal provisions shall be set out as accurately as possible; and a copy of the relevant enactments or, where this is not possible, a statement of the relevant law and as accurate a description as possible of the pers on claimed, together with any other information which will help to establish his identity and nationality.

\subsection{Surrender of the pers on to be extradited}

The requested Party shall inform the requesting Party by the means mentioned in Article 12, paragraph 1 , of its decision with regard to the extradition.

Reasons shall be given for any complete or partial rejection.

If the request is agreed to, the requesting Party shall be informed of the place and date of surrender and of the length of time for which the person claimed was detained with a view to surrender.

Subject to the provisions of paragraph 5 of this article, if the person claimed has not been taken over on the appointed date, he may be released after the expiry of 15 days and shall in any case be released after the expiry of 30 days. The requested Party may refuse to extradite him for the same offence.

If circumstances beyond its control prevent a Party from surrendering or taking over the person to be extradited, it shall notify the other Party. The two Parties shall agree a new date for surrender and the provisions of paragraph 4 of this article shall apply.

\section{Additional Protocol To The European Convention On Extradition}

According to article 2 of this protocolby which article 9 shall be supplemented to the European convention. The extradition of a pers on against whoma finaljudgment has been rendered in a third State, Contracting Party to the Convention, for the offence or offences, in respect of which the claim was made, shall not be granted:

- If the afore-mentioned judgment resulted in his acquittal;

- If the term of impris onment or other measure to which he was sentenced:

- Has been completely enforced;

- Has been wholly, or with respect to the part not enforced, the subject of a pardon or an amnesty;

- If the court convicted the offender without imposing a sanction.

- However, in the cases referred to in paragraph 2, extradition may be granted:

- If the offence in respect of which judgment has been rendered was committed against a person, an institution or anything having public status in the requesting State;

- If the person on whom judgment was passed had himself a public status in the requesting State;

- if the offence in respect of which judgment was passed was committed completely or partly in the territory of the requesting State or in a place treated as its territory.

- The provisions of paragraphs 2 and 3 shall not prevent the application of wider domestic provisions relating to the effect of ne bis in idem attached to foreign criminal judgments."

\section{Second Additional Protocol of the European Convention on Extradition (17031978)}

In Article 1 of this Protocol on Extradition shall be permitted also for crimes for which the punishment may be imposed only for money. It is allowed the extradition of a person for offenses related to taxes, fees, foreign assets, if the offense in place of the person whose extradition is requested corresponds to the offense of the same nature.

In the second additional protocol is regulated the is sue of bringing the verdict in absentia. When a state seeks extradition from another state for the execution of the sentence imposed by a decision adopted in absentia, another state may refuse the reason that the procedure in which the judgment was passed was not satis fied the minimum rights ofdefense. But this extradition is only possible if the State that requires 
submits some sort of conviction or proof that the procedure will repeat and will respect the rights of defense.

Extradition shall not be granted to the accused for the crimes committed by which from the state which is required measures of amnesty are imposed.

Extradition request is made in the written form and it is handed to the Ministry of Justice of the country from which the extradition is requested. This can be done through diplomatic channels and through direct agreement between two parties

European Convention on Extradition allows member countries (signatories) to give their reserves for certain provisions, e.g., Republic of Macedonia has submitted the following reservations:

Republic of Macedonia will not allow extradition if the convicted person should be put to the extraordinary trial, or relates to any offense that has imposed the court. In accordance with Article 4 of the Constitution of the Republic of Macedonia, which prohibits giving citizens in the Republic of Macedonia, provisions of this Convention shall apply also for the people who are not citizens of the Republic of Macedonia.

If judgment of imprisonment is imposed for granted by the court or judge in the state which is a signatory to this convention, our country may refuse extradition request, if it is determined that this judgment of imprisonment is incorrectly designed.

If the person sought for extradition is not received by the requesting State within certain period of time, then our country has the right to immediately cancel the extent of the deprivation from liberty, which was imposed on to the person in question.

\section{Third Additional Protocol of the European Convention on Extradition (10112010)}

The obligation to extradite with simplified procedure, contracting Parties undertake to extradite to each other with the simplified procedure as provided by this protocol wanted persons in accordance with Article 1 of the Convention as subject to the consent of these persons and asked party agreement.

If the person sought is the subject of a request for provisional arrest, in accordance with Article 16 of the Convention, extradition mentioned in Article 1 of this Protocol is not subject to the submission of a request for extradition and supporting documents in accordance with Article 12 of the Convention. The following information provided by the requesting party deemed appropriate by the party seeking to enhance implementation of Articles 3 to 5 of this Protocol, and taking a final decision on simplified extradition procedure: a) the identity of the person sought, including his nationality or nationalities when available. b) the authority seeking the arrest; c) the existence of an arrest warrant or other document having the same legal effect or of an enforceable decision, and a confirmation that the pers on is required in accordance with Article 1 of the Convention; d) type and description of the criminal law, including the maximum penalty or punishment provided in the final decision, including whether any part of the decision is executed; e) information about time and its termination; f) description of the circumstances in which the offense was committed, including the time, place and degree of involvement of the person sought; g) consequences of the offense, to the extent possible; h) in cases where extradition is sought to enforce a final decision, if the decision was rendered in absentia.

The consent of the pers on sought and, if appropriate, the expressed waiver of his right to rule of specialty given before the competent judicial authority of the requested party in accordance with the law of that party. Consent and, where appropriate, waivers, as referred to in paragraph 1, are registered in accordance with the law of the requested Party. According to paragraph 5, consent and, where appropriate, renunciation, as referred to in paragraph 1 , is not canceled. When the person sought has given his consent to extradition, the requested party shall notify the requesting party of its decision regarding extradition under the simplified procedure within twenty days of the date on which the person has given consent. Delivery of the pers on to be extradited must be performed as soon as possible, and preferably within ten days from the date of notification of the decision of extradition. Any non-member State which has acceded to the Convention may accede to this Protocol after it has entered into force. Reservations made by a State to any provision of the Convention or its two additional protocols, also apply to this protocol, except when that State unless otherwise stated at the time of signature or when depositing its instrument of ratification, acceptance, approval or accession. Any State may 
withdraw, in whole or in part, a reservation or declaration made in accordance with this protocol, by means of a declaration addressed to the Secretary General of the Council of Europe, which comes into force from the date of its receipt.

Any party that has made a reservation to Article 2, paragraph 1 of this Protocol in accordance with paragraph 2 of this Article may not claim the application of that paragraph by another party. However, if its reservation is partial or conditional, it may require the application of that paragraph, to the extent that it has itself accepted it.

\section{Fourth Additional Protocol of the European Convention on Extradition (20/09/2012)}

Extradition shall not be granted in cases where the prosecution or punishment of the requested person has become a prohibited status in accordance with the law of the requested Party. Extradition shall not be refused on the grounds that the prosecution or punishment of the requested person would be prohibited by law status of the requested Party Any State may, at the time of signature or when depositing its instrument of ratification, acceptance, approval or accession, declare that it reserves the right not to apply paragraph 2 in the case like:

a) when the request for extradition is based on offenses for which that state has jurisdiction under its criminal law, and / or

b) if its internal legislation explicitly prohibits extradition where prosecution or punishment of a person is claimed to be a barred statute according to its law.

Regarding extradition papers they should be a written requests from the Ministry of Justice or other competent authority of the requesting Party to the Ministry of Justice or any other authority of the requested Party. A country that wishes to appoint another competent authority shall notify the Secretary General of the Council of Europe to its competent authority at the time of signature or when depositing its instrument of ratification, acceptance, approval or accession. The application must be supported by a copy of the sentence and the order of detention or arrest or other order having the same effect and are issued in accordance with the procedure laid down in the law of the requesting party. Then a statement for each offense must be written regarding the extradition that is requested. Time and place of their commission, their legal descriptions and a reference to the relevant legal provisions, including provisions relating to time shall be determined as accurately as possible.

Transit through the territory of the Contracting Parties shall be granted upon submission of a request for transit, provided that the offense is not considered by the party seeking to grant transit as an offense of a political or military act.

As for signature and entry into force of this Protocol it shall be open for signature by member states of the Council of Europe. It is subject to ratification, acceptance or approval. A signatory may not ratify, accept or approve this Protocol without having ratified, accepted or approved the Convention in advance. Instruments of ratification, acceptance or approval shall be deposited with the Secretary General of the Council of Europe. This Protocol shall enter into force on the first day of the month following the expiration of a period of three months after the deposit of the third instrument of ratification, acceptance or approval. In respect of any signatory State which subsequently deposits its instrument of ratification, acceptance or approval, this Protocol shall enter into force on the first day of the month following the expiration of a period of three months after the date of deposit..

As regards statements and reserves, the reserves made by a state of the provisions of the Convention and its additional protocols which are not changed by this Protocol shall be applicable to this Protocol, unless that Party declares otherwise at the time of signing or when depositing its instrument of ratification, acceptance, approval or accession. Reservations and declarations made by a State to any provision of the Convention, as amended by this Protocol shall not be applicable between the Parties to this Protocol

Any State may wholly or partly withdraw a reservation or declaration made in accordance with this Protocol by notification addressed to the Secretary General of the Council of Europe, which is effective from the date of its receipt. 


\section{Conclusion}

Regarding the Extradition and separately the European Convention on Extradition with four additional protocols should be noted that our country Republic of Macedonia is a signatory to this Convention which was ratified on May 20 ${ }^{\text {th }}, 1999$ by the Assembly of Republic of Macedonia.

Convention gives to the member states the right to give any person who has committed a crime for purposes of their criminal prosecution. The Convention provides that the filing will be performed for the offense against the laws of the requesting Party and the requested Party as higher conviction is anticipated with sentence or security measure deprivation of liberty of at least one year or with more severe punishment. Also in this paper are presented deadlines for submitting requests for extradition and other procedures, communication of the contracting parties, then the declarations and re servations to a provision of the conventions and additional protocols, as well as other provisions of treatment are also subject to extradition.

\section{References}

1 .Sulejmanov, Z. (1999). Krivi nopravna pomo\{, Akademik, Skopje. [Sulejmanov, Z. (1999).

2 Criminal legal Assistance, Akademik, Skopje.]

3 Official Gazette of R.Macedonia No.32/99 A collection of international conventions, public enterprises-Official Gazette of R.M, Skopje, 2000.

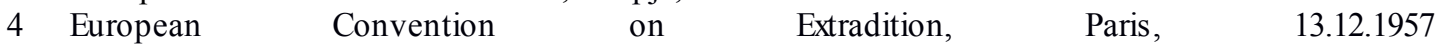
http://conventions.coe.int/Treaty/en/Treaties/Html/024.htm [accessed: 01.07.2013]

5 Additional Protocol to the European Convention of Extradition, Strasbourg, 15.10.1975 http://conventions.coe.int/Treaty/en/Treaties/Html/086.htm [accessed: 01.07.2013]

6 6.Second Additional Protocol to the European Convention of Extradition, 17.03.1978http://conventions .coe.int/Treaty/en/Treaties/Html/098.htm [accessed: 01.07.2013]

7 Third Additional Protocol to the European Convention of Extradition, Stasbourg, 10.11.2010 http://conventions.coe.int/Treaty/en/Treaties/Html/209.htm [accessed: 01.07.2013]

8 Fourth Additional Protocol to the European Convention of Extradition, Vienna, 20.09.2012 http:/conventions.coe.int/Treaty/en/Treaties/Html/212.htm [accessed: 01.07.2013] 